\title{
Constitutional law restrictions on the activities of a deputy due to changes in the constitution of the Russian Federation
}

\author{
Alla Nikolaevna Gutorova, Aleksander Nikolaevich Grokhotov, Vladimir Viktorovich \\ Korovin, Elena Aleksandrovna Masufranova, and Vladimir Vladimirovich Yatsenko \\ Southwest State University, Kursk, Russia
}

\begin{abstract}
As a result of constitutional amendments, several ideological provisions which are legally binding by constitutional requirements as a normative legal act of supreme legal force appeared in the Russian Constitution. It is necessary to determine the limits of freedom of parliamentary activity in the current conditions. The objective of the study. To analyze the deputy's activity through the prism of constitutional amendments, in the correlation of the deputy's activity as a free expression of his opinion and the established constitutional right restrictions. In this study, the formal-legal method was used to interpret the content of the constitutional amendments and the analysis method to identify the impact of the adopted amendments on the deputy activities. The analyzed constitutional provisions, having an "ideological" character, for the most part, cannot be qualified as a constitutional-legal norm. At best, it is a constitutional and legal principle, but most likely, it should be interpreted as a constitutional principle of a non-legal nature. However, at the same time, they are a legally binding rule of law. Concerning parliamentary activity, the "ideological" norms of the Russian Federation's Constitution after its amendments from 2020 play a special role. Deputies are forced to take one political position in the presence of several alternatives, which are also devoid of signs of illegality and, therefore, are legitimate and permissible in a democratic society. Therefore, in relation to deputies' activities, these amendments can be interpreted as a very significant deviation from the freedom of expression in a democratic society. These constitutional innovations significantly change some traditional ideas about the people's representation, the role of deputies in society, their obligations, and constitutional legal restrictions on their activities.
\end{abstract}

Keywords: deputy, immunity, ideology, freedom of expression

\section{Introduction}

In the Constitution of the Russian Federation, as a result of constitutional amendments, some ideological institutions have appeared which, for the most part, do not always show commonality with the "classical" constitutional principles but have a significant impact on

૫Corresponding author: allagutorova@mail.ru 
the further development of the country's legal system [1]. Based on their content, these provisions are ideological and, at the same time, legally binding due to the requirements of the Constitution of the Russian Federation as a normative legal act of the highest legal force. At the same time, the authors emphasize that Part 2 of Article 13 of the Russian Federation's Constitution prohibits the existence of a state and mandatory ideology. The provisions of Article 13 of the Constitution of the Russian Federation are higher in legal force than the provisions of Articles 67-75 of the Constitution of the Russian Federation due to the supremacy of the norms on the foundations of the constitutional system over other provisions of the Basic Law of the country. It is also noteworthy that the ideological institutions found expression in the Russian Federation's Constitution's chapter, "Federal structure", while they mainly affect the constitutional system's foundations. This is due to the complicated procedure for changing Chapters 1, 2, and 9 of the Russian Federation's Constitution, to which the initiators of the constitutional amendments preferred not to resort [2].

The phenomenon of compulsory ideology is criticized in constitutional jurisprudence not so much because of the controversial nature of the ideological statements but because of their legally binding nature [3-5]. In ideological diversity and multiparty system conditions, the citizen decides which opinion should be supported [6-9]. There should not be a constitutional and legal norm that would oblige to strictly one point of view in the presence of alternative approaches to analyzing socio-political issues.

\section{Methods}

In this study, the formal-legal method was used to interpret the content of the constitutional amendments and the analysis method to identify the impact of the adopted amendments on the deputy activities.

\section{Discussion}

Despite this, the Russian Federation's Constitution has such principles and regulations that go beyond the traditional and generally recognized constitutionalism in its international, universal meaning. First, the prohibition of calling for actions aimed at alienating part of the territory of the Russian Federation (Part 2.1 of Article 67 of the Constitution of the Russian Federation), second, preserving the memory of the ancestors who passed on to us the ideals and faith in God (Part 2 of Article 67.1 of the Constitution of the Russian Federation), third, honoring the memory of defenders of the Fatherland, ensuring the protection of historical truth, the prohibition of belittling the feat of the people in defense of the Fatherland (Part 3 of Article 67.1 of the Constitution of the Russian Federation), fourth, educating children of patriotism, citizenship, and respect for their elders (Part 4 of Article 67.1 of the Constitution of the Russian Federation).

It is essential to pay attention to the assessment of the Constitutional Court of the Russian Federation on the introduction of these amendments to the Basic Law of the country: "The inclusion of these provisions in the text of the Constitution of the Russian Federation cannot be considered incompatible with the provisions of Chapters 1 and 2 of the Constitution of the Russian Federation, in particular its Articles 1, 13, 14, 28 and 29, since, being intended to reflect the content and constitutional and legal conditions of the activities of state authorities of the Russian Federation and, to a large extent, the subjects of the Russian Federation, the proposed norms are non-political, post-partisan and non-confessional in nature and cannot be regarded, interpreted and applied as establishing a state or mandatory ideology, changing the principles of pluralistic democracy and the secular nature of the Russian state, introducing any restrictions and interference in human and civil rights and freedoms that are unacceptable 
from the point of view of Chapters 1 and 2 of the Constitution of the Russian Federation" $[1]$.

It is difficult to agree with the Constitutional Court of the Russian Federation that these constitutional provisions "cannot be regarded, interpreted and applied as establishing a state or mandatory ideology, changing the principles of pluralistic democracy and the Russian state's secular nature". A significant part of our community understands the analyzed amendments as political, party, and confessional, which define the state and mandatory ideology of the constitutional level, which is opposed to the values of pluralistic democracy.

Concerning parliamentary activity, the "ideological" norms of the Russian Federation's Constitution after its amendments from 2020 play a special role. If the legislator prohibits calls for actions aimed at alienating a part of the territory of the Russian Federation, he turns his regulatory influence to all subjects of legal relations on an equal basis, but mainly to political figures or persons interested in politics.

Under such circumstances, the position of a Russian supporting (patriotic position) or refuting (cosmopolitan position) the need to annex these territories and the legality or expediency of these actions, which were committed in the past, based on free political opinion, is quite understandable. A free opinion should be the decisive factor in resolving such political issues $[10,11]$. If the freedom of such an opinion is restricted by law, especially at the constitutional level, there is a problem of ensuring this requirement by the state's coercive force, including criminal sanctions.

In the analyzed context, it is necessary to emphasize that senators of the Russian Federation and deputies of the State Duma have parliamentary immunity, the meaning of which is not to "protect" people's representatives from criminal prosecution when they commit typical criminal acts but to prevent unconstitutional interference in parliamentary activities in the presence of controversial political circumstances. A call to change the borders of the country's territory, a critical look at the historical past, in our opinion - is precisely the case in which the application of parliamentary immunity would be most likely. Unlike parliamentarians, there are many other political figures or just citizens interested in politics but are not protected by parliamentary immunity institutions [12-14]. The authors believe that this does not fully comply with Article 19 of the Russian Federation's Constitution and needs to be evaluated by the Constitutional Court of the Russian Federation if there is a corresponding request from interested parties.

Concerning parliamentary activity, the constitutional provision on the need to "preserve our ancestors' memory and ideals" can be interpreted as a very significant deviation from the freedom of expression in a democratic society. The people's representative proposing to implement legislative and public initiatives determined by the needs of the time, who had no experience in the past, can be accused of violating the requirements of Part 2 of Article 67.1 of the Constitution of the Russian Federation. For modern Russian society, both honoring their ancestors' memory and repenting for some of their sins are equally useful to prevent the repetition of negative experiences in the present and the future $[15,16]$. An exceptionally positive view of Russian history is, in our opinion, biased and unscientific.

The problem of interpretation of the term "historical truth' in its mutual connection with the legal category "belittling of a feat" looks more complicated. Both categories are evaluative from a legal point of view, and the imperative of Part 3 of Article 67.1 of the Constitution of the Russian Federation can be interpreted as a requirement of the highest possible assessment. However, to what extent should this assessment be high? Does this mean that deputies and other political figures in public debates, election programs, when discussing draft laws and in other similar situations are constitutionally obliged to give the "highest possible assessment" of the actions of the Armed Forces of the country in all cases when it comes to the past? That is, any historical discussion in which Russia is not represented positively is a violation of the requirements of Part 3 of Article 67.1 of the Constitution of 
the Russian Federation? Under such circumstances, the depersonalized reference in the Russian Federation's Constitution to the mandatory support of deputies and other political figures for the "historical truth" is very controversial.

The constitutional amendments of an "ideological nature" in the 2020 reform on the need to establish citizenship, patriotism, and national identity in society deserve scientific support. Since the patriotic meaning of the Basic Law of Russia was supported by the preamble to the Russian Federation's Constitution and a number of its provisions, which found expression in its first and second chapters, already in 1993. Yet, this was not expressed so clearly and unambiguously from a legal point of view, which is observed due to the amendments of 2020.

The constitutional thesis on patriotism and citizenship in the constitutional amendments of 2020 is a requirement primarily addressed to all citizens of the country. If an individual is a citizen of a given state, i.e., is in a stable political and legal relationship with the constitutional sovereign, this conditions their mutual rights and obligations, including the citizen's loyalty and duty to the Fatherland, etc. This is expressed not only in the constitutional obligation of military or alternative civilian service but also in several other constitutional-legal obligations of a public nature, which need appropriate constitutional institutionalization. Thus, deputies as people's representatives are constitutionally obliged to be patriots of their country and support its global political interests.

\section{Conclusion}

The principle of political pluralism dictates the right of a deputy to choose the political position that best corresponds to his personal ideas about the people's welfare and is shared by citizens due to the support of the candidate running for the next parliamentary elections. The requirement of patriotism does not eliminate political competition and does not imply its elimination by "standardizing" election programs that meet the criteria of "patriotism". On the other hand, this shows the restriction of freedom of political thought and speech that is permissible from the constitutional standpoint (Part 3 of Article 55 of the Russian Federation's Constitution). The programs of political parties, individual deputies, and their subsequent activities in government bodies must be civil, patriotic, and support national and cultural identity and other values established by the Russian Federation's Constitution.

\section{References}

1. Zaklyuchenie Konstitutsionnogo Suda RF ot 16.03.2020 № 1-Z «O sootvetstvii polozheniyam glav 1, 2 i 9 Konstitutsii Rossiiskoi Federatsii ne vstupivshikh v silu polozhenii Zakona Rossiiskoi Federatsii o popravke k Konstitutsii Rossiiskoi Federatsii "O sovershenstvovanii regulirovaniya otdelnykh voprosov organizatsii i funktsionirovaniya publichnoi vlasti», a takzhe o sootvetstvii Konstitutsii Rossiiskoi Federatsii poryadka vstupleniya v silu stati 1 dannogo Zakona v svyazi s zaprosom Prezidenta Rossiiskoi Federatsii" [Conclusion of the Constitutional Court of the Russian Federation of 16.03.2020 No. 1-Z "On compliance with the provisions of Chapters 1, 2 and 9 of the Constitution of the Russian Federation of the Provisions of the Law of the Russian Federation on Amendments to the Constitution of the Russian Federation "On improving the regulation of certain issues of the organization and functioning of public power", as well as on compliance with the Constitution of the Russian Federation of the procedure for entry into force of Article 1 of this Law in connection with the request of the President of the Russian Federation"], Code of Laws RF 12, 1855 (2020)

2. V.P. Zhuravlev, Elect. Leg. and Pract. 2, 3-7 (2020) 
3. E.N. Chernolutskaya, Russia and APR. 4, 34-47 (2015)

4. I.A. Kravets, Law and Politics, 9, 1432-1458 (2014). https://doi.org/10.7256/18119018.2014.9.12859

5. A. Medushevsky, Comp. Constit. Rev. 3, 124-135 (2018)

6. M. Morfit, Asian Surv. 21(8), 838-851 (1981)

7. N. Bekus, Polish Soc. Rev. 163(3), 263-283 (2008)

8. M. Slocomb, J. SE Asian Stud. 37(03), 375-395 (2006). https://doi.org/10.1017/S0022463406000695

9. F.E. Lee, Beyond ideology: Politics, principles, and partisanship in the US Senate (University of Chicago Press, Chicago, 2009)

10. I.S. Iksanov, Modern Lawyer, 1, 54 (2015)

11. A.A. Kulagin, Sc. Bul. Volgograd branch of the RANEPA. Ser.: Jurisprudence 2, 128 (2015)

12. V.K. Mircheva, Lex Russica, 66(6), 1233 (2007)

13. D.V. Pazhetnykh, E.V. Kolesnikov, Constit. and Municipal Law 6, 23 (2009)

14. G.A. Trofimova, Rus. Legal J. 2, 83 (2016)

15. V.V. Onishchenko, Izv. Altai State Univ. 4, 148 (2009)

16. A.A. Amosova, Modern Hist. of Rus. 1, 153 (2011) 